\title{
PENGARUH 4P DAN KUALITAS LAYANAN TERHADAP KINERJA PEMASARAN MELALUI MOTIVASI MEMBELI - AGEN PERUSAHAAN PT. ERATAMA PUTRA MANDIRI BANYUWANGI
}

\author{
Ice Ratna Kumala \\ Mahasiswa Magister Manajemen Pascasarjana Universitas Islam Malang \\ Email : ice.kumala@yahoo.com
}

\begin{abstract}
Abstrak
Penelitian ini bertujuan untuk menganalisa pengaruh 4P dan kuualitas layanan terhadap kinerja melalui motivasi membei Agen Perusahaan terhadap kinerja PT. Eratama Putra Mandiri Banyuwangi. Analisis data menggunakan SEM Structural Sqution Model) Dan program PLS GSCA. Populasi penelitian ini berjumlah 130 Agen dan sampel yang diambil 60 Age dengan metode Convenience sampling. Hasil penelitiian menunjukkan bahwa : Dari persamaan struktural dapat diketahui hubungan konstruk laten eksogen terhadap konstruk laten endogen. terlihat bahwa variabel Kinerja (Y)lebih dominan dipengaruhi oleh variabel latent Motivation (X3) yaitu dengan nilai pengaruh tertinggi sebesar 0,587adalah $58.7 \%$. Sedangkan Motivation (X3) ternyata lebih dominan dipengaruhi oleh variabel Service Quality (X2), dimana indikator (variabel manifest) yang paling baik dalam membentuk variabel Service Quality (X2) adalah X2.5 (Empaty) dengan loading faktor tertinggi sebesar 0,893adalah 89,3\%. Dengan demikian apabila pihak manajemen ingin meninggikan nilai variabel Service Quality (X2) maka rekomendasi secara statistik mengenai indikator perlu diprioritaskan untuk diperbaiki adalah indikator X2.5 (Empaty)

Kata Kunci: Kualitas Layanan, Motivasi membeli, Kinerja Pemasaran
\end{abstract}

\begin{abstract}
This study aims to analyze the influence of $4 P$ and the quality of service to performance through buying motivation Agent Company to the performance of PT. Eratama Putra Mandiri Banyuwangi. Data analysis using SEM Structural Equation Model) and GSCA PLS program The population of this study amounted to 130 Agents and samples taken 60 Agen by the method. Marketing Mix Analysis and quality of service to motivation to buy Consument to buy Fish Products in PT Eratama Putra Mandiri. Continuity of a company can be influenced by the marketing strategy and quality of service performed by the company given to influence the motivation of consumers to buy. This study aims to determine the effect of $4 P$ marketing and service quality that has been done by the company PT. Eratama Putra Mandiri in affecting Motivation buy products by customers to buy Seafood Product. The results showed that: Equations we can know the relationship of exogenous latent constructs to endogenous latent constructs. it can be seen that performance variable $(Y)$ is more dominant influenced by latent motivation variable (X3) that is with highest value of influence equal to 0,587 is $58,7 \%$. While Motivation (X3) is more dominantly influenced by Service Quality (X2) variable, where the best indicator (variable manifest) in establishing Service Quality (X2) variable is X2.5 (Empathy) with loading factor highest is 0.893 is $89 \%$. Thus if the management wants to raise the value of Service Quality (X2) variable then the statistical recommendation of the indicators should be prioritized for improvement is the indicator X2.5 (Empathy)
\end{abstract}

Keywords: Marketing Mix 4P, Service Quality, Buying Motivation 


\section{PENDAHULUAN}

Ikan sebagai sumber protein sangat relevan untuk mendukung program prioritas pemerintah dalam rangka meningkatkan kualitas hidup masyarakat Indonesia dan meningkatkan kemandirian ekonomi berbasis pada kelautan dan perikanan. Menurut Nilanto, pelaksanaan program GEMARIKAN tidak hanya menjadi tugas dari Kementerian Kelautan dan Perikanan sebagai instansi teknis yang membidangi kelautan dan perikanan, namun juga menjadi tugas seluruh komponen institusi, lembaga, dan masyarakat dalam rangka mempersiapkan generasi bangsa yang sehat dan cerdas. Oleh karena itu dibutuhkan strategi, koordinasi, dan harmonisasi yang melibatkan seluruh komponen bangsa, yang salah satunya dengan pembentukan FORIKAN.

Berhasil tidaknya dalam pencapaian tujuan bisnis tergantung pada keahlian di bidang pemasaran. Selain itu juga tergantung pada kemampuan untuk mengkombinasikan fungsi-fungsi tersebut agar dapat berjalan lancar. Pemasaran adalah proses sosial dan manajerial yang membuat individu dan kelompok memperoleh apa yang mereka perlukan dan inginkan melalui penciptaan dan pertukaran timbal balik produk dan nilai dengan orang lain (Kotler, 2016:10). Strategi pemasaran 4P harus disusun secara efektif oleh perusahaan dalam rangka memenuhi kebutuhan dan keinginan pelanggan dengan cara yang lebih baik dari pada pesaing, Kotler dan Keller, 2016. Hal ini penting dilakukan agar perusahaan mampu bersaing dengan perusahaan lain. Di sisi lain perusahaan juga harus memperhatikan Kualitas Layanan yang diberikan kepada pelanggan. Apalagi perusahaan jasa seperti perusahaan PT Eratama Putra Mandiri Banyuwangi ini. Kualitas layanan adalah hal yang sangat penting bagi perusahaan jasa, Valerie $A$, Zeithaml dan Dgramler, 2013. Strategi 4P yang efektif dan Kualitas layanan yang prima akan meningkatkan motivasi membeli pelanggan terhadap produk yang ditawarkan oleh perusahaan. Sehingga pada akhirnya motivasi yang tinggi akan berdampak pula pada meningkatnya penjualan ( kinerja Pemasaran).

1. Product (Produk) adalah produk adalah semua hal yang dapat ditawarkan kepada pasar untuk menarik perhatian, akuisisi, penggunaan, atau konsumsi yang dapat memuaskan suatu keinginan atau kebutuhan (Kotler dan Amstrong, 2008:266).

2. Price (Harga) Menurut Kotler \& Keller (2016) "harga adalah salah satu elemen bauran pemasaran yang menghasilkan pendapatan; elemen lain menghasilkan biaya. Harga juga mengkomunikasikan positioning nilai yang dimaksudkan dari produk atau merek perusahaan ke pasar."

3. Place (Tempat). Menurut Kotler \& Keller (2016: 14)"Saluran distribusi adalah untuk menggelar, menjual, atau menyampaikan produk fisik atau jasa kepada pelanggan atau pengguna. Saluran distribusi dapat mencakup toko fisik maupuntoko-toko virtual di internet. Strategi distribusi bertujuan untuk memberi kemudahan kepada konsumen dalam menemukan informasi dan keberadaan produk"

4. Promotion Menurut Philip Kotler, (promosi adalah berbagai kegiatan yang dilakukan oleh perusahaan yang menonjolkan keistimewaan- 
keistimewaan produknya yang membujuk konsumen sasaran agar membelinya.

Perusahaan juga harus memperhatikan Kualitas Layanan yang diberikan kepada pelanggan. Apalagi perusahaan jasa seperti perusahaan PT Eratama Putra Mandiri Banyuwangi ini. Kualitas layanan adalah hal yang sangat penting bagi perusahaan jasa, Valerie $A$, Zeithaml dan Dgramler, 2013.

Sedangkan kualitas menurut ISO 9000 (dalam Lupiyoadi \& Hamdani, 2001), adalah: "degree to which a set ofinherent characteristics fulfils requirements" (derajat yang dicapai oleh karakteristik yang bersatu padu dalam memenuhi persyaratan). Jadi, kualitas sebagaimana yang diinterpretasikan ISO 9000 merupakan perpaduan antara sifat dan karakteristik yang menentukan sejauh mana keluaran dapat memenuhi persyaratan kebutuhan.

\section{KAJIAN TEORI}

Konsep kualitas sendiri pada dasarnya bersifat relatif, yaitu tergantung dari perspektif yang dipakai dalam penentuan ciri-ciri dan spesifikasi. Pada intinya terdapat tiga orientasi kualitas yang seharusnya konsisten satu sama lain: (1) persepsi konsumen, (2) produk, dan (3) proses. Untuk yang berwujud barang, ketiga orientasi ini hampir selalu dapat dibedakan dengan jelas, tetapi tidak untuk jasa. Kualitas layanan adalah hal yang sangat penting bagi perusahaan jasa, Valerie $A$, Zeithaml dan Dgramler, 2013.

Motivasi adalah kegiatan yang dilakukan seseorang didorong oleh sesuatu kekuatan dari dalam diri seseorang, kekuatan pendorong (Drive ) inilah yang disebut dengan motivasi, pada penelitian kali ini peneliti melakukan penelitian motivasi membeli terhadap suatu produk yang ada pada PT. Eratama Putra Mandiri. Banyak teori yang mendasari beberapa teori motivasi, motivasi yang ada pada seseorang akan mewujudkan suatu perilaku yang diarahkan pada tujuan mencapai kepuasan (Sukanto dan Hani H. 1986)

Kinerja pemasaran merupakan strategi pemasaran guna mencapai target yang telah ditentukan oleh Perusahaan secara keseluruhan, dimana setiap target ada batasan yang harus dicapai melaui penjualan yang terealisasi pada waktu yang ditentukan.

Konsep ini ditujukan untuk mengukur prestasi pemasaran suatu perusahaan dan merupakan salah satu cermin dari penerapan strategi perusahaan. Ferdinand A.T. (2000) "menyatakan bahwa kinerja pemasaran merupakan faktor yang sering kali digunakan untuk mengukur dampak dari strategi yang diterapkan perusahaan.. Motivasi dapat digambarkan sebagai kekuatan dari dalam individu yang yang mendorong untuk bereaksi (Schiffman \& Kanuk, 2000:63).

Strategi 4P yang efektif dan Kualitas layanan yang prima akan meningkatkan motivasi membelipelanggan terhadap produk yang ditawarkan oleh perusahaan. Sehingga pada akhirnya motivasi yang tinggi akan berdampak pula pada meningkatnya penjualan ( kinerja Pemasaran) 
Oleh karena itu perlu dibuktikan dan dianalisis tentang penyebab naik turunnya kinerja pemasaran perusahaan PT Eratama Putra Mandiri Banyuwangi, melalui variabel 4P , Kualitas Layanan dan motivasi membeli para pelanggan

\section{METODE PENELITIAN}

Jenis Penelitan ini adalah kausatif, peneliti ingin menguji pengaruh 4P terhadap kinerja melalui variabel motivasi membeli dengan menggunakan alat penelitian Structural equation modeling, SEM Definisi berikutnya mengatakan bahwa Structural equation modeling (SEM) merupakan teknik statistik yang digunakan untuk membangun dan menguji model statistik yang biasanya dalam bentuk model-model sebab akibat.

Penelitian dilakukan di Banyuwangi Pada Perusahaan pengolahan ikan PT. Eratama Putra Mandiri . Waktu yang dibutuhkan dalam penelitian ini diimulai bulan 01 Februari - 30 April 2018. Populasi dalam penelitian ini adalah seluruh Agen pemasaran PT Eratama Putra Mandiri Banyuwangi yang tersebar di seluruh Indonesia dari Agendan rekanan yang sejumlah 130Agen. Jumlah pengambilan sampel yang diperoleh sebesar 63, yang tidak lengkap pengisiannya sebesar 3 agen sehingga yang digunakan sebagai sampel sejumlah 60.

Tehnik Pengumpulan Data yang akan dalam penelitian ini adalah:Observasi, wawancara, dan studi pustaka dan kuesioner. Metode pengumpulan data dalam penelitian ini adalah daftar kuesioner yang diberikan kepada konsumen PT. Eratama Putra Mandiri. Dalam memberikan daftar pertanyaan adalah yang paling mudah dan efektif untuk dijawab oleh Agen atau pembeli produk. Metode pengumpulan Data yang akan digunakan adalah melalui, wawancara, observasi, studi pustaka dan kuesioner.

Model persamaan Struktural atau Struktural Equation Modeling (SEM). Merupakan alat analisis yang tepat untuk menguji secara simultan antara multiple eksogen dan endogen variabel dengan banyak indikator. Sebagai Alternatif, Generalized structured component analysis (GSCA) menawarkan kemampuan bagi peneliti untuk analisis SEM. Tujuannya adalah menggantikan faktor dengan kombinasi linier dari indikator (variabel manifes) di dalam analisis SEM. Pendekatan analisis ini menggunakan metode kuadrat terkecil (least square) di dalam proses pendugaan parameter. GSCA dikembangkan untuk menghindari kekurangan PLS (Partial Least Square), yaitu dilengkapi prosedur optimalisasi global seperti prosedur dalam SEM, juga tetap mempertahankan prosedur optimalisasi lokal (seperti pada PLS) sehingga powerfull untuk konfirmasi teori.

Tahap ini berkaitan dengan pembentukan model awal model awal persamaan structural, sebelum dilakukan estimasi. Spesifikasi model penelitian, yang merepersentasikan permasalahan yang diteliti, adalah penting di dalam Persamaan Struktural. Adapun model persamaan struktural yang akan di konstruksikan dalam penelitian ini sebagaimana pada gambar berikut ini: 
Uji kecocokan keseluruhan model berkaitan dengan analisis terhadap GOF statistik yang dihasilkan oleh program, dalam hal ini GSCA. Dengan menggunakan pedoman ukuran-ukuran GOF dan hasil GOF statistic. Berikut ini beberapa indeks kesesuaian dan cut-off value untuk menguji apakah sebuah model dapat diterima atau ditolak.

Metode yang digunakan yaitu Confirmatory Factor Analysis, dimana dengan menggunakan alat ini akan diketahui indikator-indikator yang ada memang benar-benar dapat menjelaskan sebuah konstruk. Indikatorindikator yang digunakan untuk merefleksikan suatu variabel juga mengandung error, sehingga juga harus dipertimbangkan dalam analisis statistic.

Pengujian hipotesis dengan mengevaluasi koefisien-kofisien atau parameter-parameter yang menunjukkan hubungan kausal atau pengaruh satu variabel laten terhadap variabel laten lainnya. Sebuah hubungan kausal dinyatakan tidak signifikan jika nilai critical ratio (C.R.) berada diantara rentang -1.96 dan 1.96 dengan tingkat signifikansi 0,05.

\section{HASIL ANALISIS DATA}

Hasil penelitian diuraikan secara rinci sesuai masing - masing variable untuk mengetahui nilai atau score yang tertinggi untuk menentukan metode perbaikan pada variable yang terkait.

Teknik analisis deskriptif bertujuan untuk menjelaskan mengenai keseluruhan data yang dikumpulkan dengan memaparkan, mengelompokkan, dan mengklasifikasikan ke dalam tabel yang kemudian diberi penjelasan berdasarkan indikator yang paling dominan dan indikator terlemah. Dengan demikian criteria untuk mendeskripsikan nilai mean yang telah diperoleh setiap butir, indicator, dan variabel dapat dideskripsikan pada tabel 4.1 adalah sebagai berrikut :

Tabel 4.1

Dasar Interpretasi Skor Indikator Dalam Variabel Penelitian

\begin{tabular}{|l|l|l|}
\hline No & Nilai / Skor & Interpretasi \\
\hline 1 & $1-1,8$ & Sangat rendah / Buruk \\
\hline 2 & $>1,8-2,6$ & Rendah / Kurang baik \\
\hline 3 & $>2,6-3,4$ & Sedang / Cukup baik \\
\hline 4 & $>3,4-4,2$ & Tinggi / Baik \\
\hline 5 & $>4,2-5,0$ & Sangat Tinggi / Sangat Baik \\
\hline
\end{tabular}

Sumber : Sujana, 2001.

Hasil penelitian dan perhitungan pada kuesionair yang disebar di uraikan berikut di bawah ini ; 
Tabel 4.2

Distribusi Tanggapan Responden pada Variabel

\begin{tabular}{|c|c|c|c|c|c|c|c|c|c|}
\hline \multirow{2}{*}{ No } & \multirow{2}{*}{$\begin{array}{lr}\text { Item pada } \\
\text { Pelayanan (X2) }\end{array}$} & & \multicolumn{5}{|c|}{ Alternatif Jawaban } & \multirow{2}{*}{ Mean } & \multirow{2}{*}{ Kategori } \\
\hline & & & SS & $\mathbf{S}$ & $\mathbf{N}$ & TS & STS & & \\
\hline \multirow{2}{*}{1} & \multirow{2}{*}{ Pengiriman produk cepat } & $\mathrm{F}$ & 13 & 29 & 13 & 5 & 0 & \multirow{2}{*}{3,83} & \multirow{2}{*}{ Tinggi } \\
\hline & & $\%$ & 21,7 & 48,3 & 21,7 & 8,3 & 0 & & \\
\hline \multirow{2}{*}{2} & \multirow{2}{*}{$\begin{array}{l}\text { Waktu yang dibutuhkan untuk } \\
\text { staffing dan penataan produk } \\
\text { baik dan tertata }\end{array}$} & $\mathrm{F}$ & 17 & 28 & 13 & 2 & 0 & \multirow{2}{*}{4} & \multirow{2}{*}{ Tinggi } \\
\hline & & $\%$ & 28,3 & 46,7 & 21,7 & 3,3 & 0 & & \\
\hline \multirow{2}{*}{3} & \multirow{2}{*}{$\begin{array}{l}\text { kondisi produk sesuai dengan } \\
\text { Physiknya }\end{array}$} & $\mathrm{F}$ & 13 & 28 & 15 & 4 & 0 & \multirow{2}{*}{3,83} & \multirow{2}{*}{ Tinggi } \\
\hline & & $\%$ & 21,7 & 46,7 & 25 & 6,7 & 0 & & \\
\hline \multicolumn{2}{|c|}{ Realbility (X2.1) } & & & & & & & 3,89 & Tinggi \\
\hline \multirow{2}{*}{4} & \multirow{2}{*}{$\begin{array}{l}\text { Sesuai dengan spesifikasi dari } \\
\text { permintaan konsumen }\end{array}$} & $\mathrm{F}$ & 7 & 37 & 12 & 4 & 0 & \multirow{2}{*}{3,78} & \multirow{2}{*}{ Tinggi } \\
\hline & & $\%$ & 11,7 & 61,7 & 20 & 6,7 & 0 & & \\
\hline \multirow{2}{*}{5} & \multirow{2}{*}{$\begin{array}{l}\text { Akurasi penataan ikan cukup } \\
\text { baik }\end{array}$} & $\mathrm{F}$ & 9 & 32 & 17 & 2 & 0 & \multirow{2}{*}{3,8} & \multirow{2}{*}{ Tinggi } \\
\hline & & $\%$ & 15 & 53,3 & 28,3 & 3,3 & 0 & & \\
\hline & PO ( order pembelian ) sesuai & $\mathrm{F}$ & 10 & 29 & 18 & 3 & 0 & & \\
\hline 6 & $\begin{array}{ll}\text { dengan } & \text { permintaan } \\
\text { konsumen. } & \end{array}$ & $\%$ & 16,7 & 48,3 & 30 & 5 & 0 & 3,77 & IInggI \\
\hline Res & ponsiveness (X2.2) & & & & & & & 3,78 & Tinggi \\
\hline 7 & PT. EPM memberikan jaminan & $\mathrm{F}$ & 8 & 31 & 19 & 2 & 0 & 375 & \\
\hline 7 & kualitas produk ikan & $\%$ & 13,3 & 51,7 & 31,7 & 3,3 & 0 & 3,15 & IInggI \\
\hline & PT. $\quad$ EPM bersedia & $\mathrm{F}$ & 11 & 33 & 13 & 3 & 0 & & \\
\hline 8 & $\begin{array}{l}\text { memberikan fleksibilitas } \\
\text { dalam pengiriman ikan }\end{array}$ & $\%$ & 18,3 & 55 & 21,7 & 5 & 0 & 3,87 & Tinggi \\
\hline 9 & PT. EPM memberikan jaminan & $\mathrm{F}$ & 12 & 30 & 15 & 3 & 0 & 385 & Tingai \\
\hline 9 & produk ikan & $\%$ & 20 & 50 & 25 & 5 & 0 & 3,85 & IInggI \\
\hline Ass & urance (X2.3) & & & & & & & 3,82 & Tinggi \\
\hline & PT.EPM member keyakinan & $\mathrm{F}$ & 10 & 32 & 14 & 4 & 0 & & \\
\hline 10 & $\begin{array}{l}\text { produk yang bagus kepada } \\
\text { konsumen }\end{array}$ & $\%$ & 16,7 & 53,3 & 23,3 & 6,7 & 0 & 8 & Tinggi \\
\hline 11 & $\begin{array}{llr}\text { PT. } & \text { EPM memperhatikan } \\
\end{array}$ & $\mathrm{F}$ & 8 & 32 & 16 & 4 & 0 & 373 & Tingai \\
\hline & Agen - pembeli produk & $\%$ & 13,3 & 53,3 & 26,7 & 6,7 & 0 & & iming? \\
\hline 12 & PT. EPM bersedia menerima & $\mathrm{F}$ & 8 & 33 & 15 & 4 & 0 & 375 & ngai \\
\hline 16 & mutu produk dari konsumen & $\%$ & 13,3 & 55 & 25 & 6,7 & 0 & 3,15 & linggI \\
\hline$E m_{l}$ & Dhaty (X2.4) & & & & & & & 3,76 & Tinggi \\
\hline 13 & PT. EPM menyediakan tempat & $\mathrm{F}$ & 20 & 22 & 15 & 3 & 0 & 398 & \\
\hline 10 & penyimpana ikan yang bersih & $\%$ & 33,3 & 36,7 & 25 & 5 & 0 & 3,90 & yl \\
\hline 11 & PT. EPM menyediakan deng & $\mathrm{F}$ & 27 & 16 & 14 & 3 & 0 & & \\
\hline & storage sirkulasi baik & $\%$ & 45 & 26,7 & 23,3 & 5 & 0 & 4,16 & inigyi \\
\hline 15 & $\begin{array}{lll}\text { PT. } & \text { EPM menyiapakn }\end{array}$ & $\mathrm{F}$ & 25 & 18 & 15 & 2 & 0 & & \\
\hline 15 & pembatas atas peta produk & $\%$ & 41,7 & 30 & 25 & 3,3 & 0 & 4,1 & 1 Iniggi \\
\hline Tan & gible (X2.5) & & & & & & & 4,07 & Tinggi \\
\hline
\end{tabular}




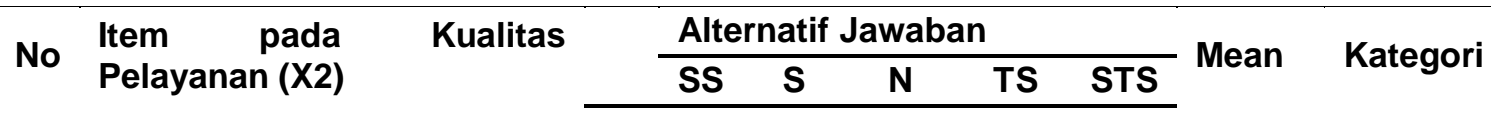

Distribusi Tanggapan Responden pada Variabel Motivasi (X3)

\begin{tabular}{|c|c|c|c|c|c|c|c|c|c|}
\hline \multirow[b]{2}{*}{ No } & Item pada Motivasi & Motivasi & \multicolumn{5}{|c|}{ Alternatif Jawaban } & \multirow{2}{*}{ Mean } & \multirow{2}{*}{ Katego } \\
\hline & (X3) & & SS & $\mathbf{S}$ & $\mathbf{N}$ & TS & STS & & \\
\hline \multirow[t]{2}{*}{1} & \multirow{2}{*}{$\begin{array}{l}\text { Agen selalu membeli } \\
\text { ikan di PT. EPM karena } \\
\text { margin lebih besar }\end{array}$} & $\mathrm{F}$ & 6 & 39 & 10 & 5 & 0 & & \\
\hline & & $\%$ & 10,0 & 65,0 & 16,7 & 8,3 & 0,0 & 3,77 & Tinggi \\
\hline \multirow[t]{2}{*}{2} & \multirow{2}{*}{$\begin{array}{l}\text { Agen mendapat harga } \\
\text { lebih murah dari pabrik } \\
\text { Pesang PT. EPM }\end{array}$} & $F$ & 6 & 34 & 16 & 4 & 0 & & \\
\hline & & $\%$ & 10,0 & 56,7 & 26,7 & 6,7 & 0,0 & 3,70 & Tinggi \\
\hline \multirow[t]{2}{*}{3} & \multirow{2}{*}{$\begin{array}{l}\text { Pelayanan lebih ramah } \\
\text { dan menyenangkan }\end{array}$} & $\mathrm{F}$ & 13 & 33 & 9 & 5 & 0 & \multirow{2}{*}{3,90} & \multirow{2}{*}{ Tinggi } \\
\hline & & $\%$ & 21,7 & 55,0 & 15,0 & 8,3 & 0,0 & & \\
\hline \multirow{2}{*}{\multicolumn{2}{|c|}{$\begin{array}{l}\text { Akumulasi } \\
\text { Responden }\end{array}$}} & $\mathrm{F}$ & 25 & 106 & 35 & 14 & 0 & \multirow{2}{*}{3,79} & \multirow{2}{*}{ Tinggi } \\
\hline & & $\%$ & 13,89 & 58,89 & 19,44 & $\mathbf{7 , 7 8}$ & 0,00 & & \\
\hline
\end{tabular}

Distribusi Tanggapan Responden pada Variabel Y Kinerja (Penjualan)

\begin{tabular}{|c|c|c|c|c|c|c|c|c|c|}
\hline \multirow[b]{2}{*}{ No } & \multirow{2}{*}{\multicolumn{2}{|c|}{$\begin{array}{l}\text { Item pada Y Kinerja } \\
\text { (Penjualan) }\end{array}$}} & \multicolumn{5}{|c|}{ Alternatif Jawaban } & \multirow[b]{2}{*}{ Mean } & \multirow[b]{2}{*}{ Kategori } \\
\hline & & & SS & $\mathbf{S}$ & $\mathbf{N}$ & TS & STS & & \\
\hline \multirow[t]{2}{*}{1} & Semua Produk habis & $\mathrm{F}$ & 11 & 30 & 15 & 4 & 0 & \multirow[b]{2}{*}{3,80} & \multirow[b]{2}{*}{ Tinggi } \\
\hline & $\begin{array}{l}\text { terjual sesaui stok yg } \\
\text { diolah - in process data }\end{array}$ & $\%$ & 18,3 & 50,0 & 25,0 & 6,7 & 0,0 & & \\
\hline \multirow[t]{2}{*}{2} & Margin dari setiap & $\mathrm{F}$ & 12 & 32 & 15 & 1 & 0 & \multirow[b]{2}{*}{3,92} & \multirow[b]{2}{*}{ Tinggi } \\
\hline & $\begin{array}{l}\text { produk yang dijual lebih } \\
\text { dari } 5 \%\end{array}$ & $\%$ & 20,0 & 53,3 & 25,0 & 1,7 & 0,0 & & \\
\hline \multirow{2}{*}{\multicolumn{2}{|c|}{$\begin{array}{l}\text { Akumulasi } \\
\text { Responden }\end{array}$}} & $\mathrm{F}$ & 23 & 62 & 30 & 5 & 0 & \multirow{2}{*}{3,86} & \multirow{2}{*}{ Tinggi } \\
\hline & & $\%$ & 19,17 & 51,67 & 25,00 & 4,17 & 0,00 & & \\
\hline
\end{tabular}

Hasil Penelitian menunjukkan bahwa akumulasi rata-rata (Mean) semua jawaban per item dalam variabel Motivasi (X3) sebesar 3,79. Sehingga dapat disimpulkan bahwa secara umum variabel Motivasi (X3) termasuk dalam kategori Tinggi.

\section{PEMBAHASAN}

Pada variabel Marketing Mix 4P (X1) diukur menggunakan 4 indikator. Masing-masing jawaban memiliki nilai, kemudian skor jawaban diakumulasikan yang selanjutnya digunakan untuk mengkategorikan variabel berdasarkan rata-rata jawaban responden. Berikut disajikan distribusi frekuensi tanggapan responden terhadap variabel Marketing Mix 4P (X1).

Tabel 5.1

Distribusi Tanggapan Responden pada Variabel Marketing Mix 4P (X1)

\begin{tabular}{|c|c|c|c|c|c|c|c|c|c|}
\hline \multirow{2}{*}{ No } & \multirow{2}{*}{$\begin{array}{l}\text { Item pada Marketing Mix } \\
4 \mathrm{P}(\mathrm{X} 1)\end{array}$} & & \multicolumn{5}{|c|}{ Alternatif Jawaban } & \multirow{2}{*}{ Mean } & \multirow{2}{*}{ Kategor } \\
\hline & & & SS & S & $\mathbf{N}$ & TS & STS & & \\
\hline \multirow[t]{2}{*}{1} & Produk sesuai dengan & $\mathrm{F}$ & 17 & 28 & 12 & 3 & 0 & \multirow[b]{2}{*}{3,98} & \multirow[b]{2}{*}{ Tinggi } \\
\hline & $\begin{array}{l}\text { ukuran dan jenis yang } \\
\text { diinginkan oleh konsumen }\end{array}$ & $\%$ & 28,3 & 46,7 & 20,0 & 5,0 & 0,0 & & \\
\hline 2 & & $\mathrm{~F}$ & 22 & 14 & 19 & 5 & 0 & 3,88 & Tinggi \\
\hline
\end{tabular}




\begin{tabular}{|c|c|c|c|c|c|c|c|c|c|}
\hline \multirow{3}{*}{ No } & \multirow{2}{*}{$\begin{array}{l}\text { Item pada Marketing Mix } \\
\text { 4P (X1) }\end{array}$} & & \multicolumn{5}{|c|}{ Alternatif Jawaban } & \multirow{3}{*}{ Mean } & \multirow{3}{*}{ Kategor } \\
\hline & & & ss & \multirow{2}{*}{$\frac{\mathbf{S}}{23,3}$} & \multirow{2}{*}{$\frac{\mathbf{N}}{31,7}$} & \multirow{2}{*}{$\begin{array}{l}\text { TS } \\
8,3\end{array}$} & \multirow{2}{*}{$\begin{array}{c}\text { STS } \\
0,0\end{array}$} & & \\
\hline & $\begin{array}{l}\text { Harga ikan sesuai dengan } \\
\text { daya beli konsumen }\end{array}$ & $\%$ & 36,7 & & & & & & \\
\hline \multirow[t]{2}{*}{3} & \multirow{2}{*}{$\begin{array}{l}\text { Lokasi Pabrik strategis } \\
\text { dapat dijangkau dengan } \\
\text { mudah oleh konsumen }\end{array}$} & $\mathrm{F}$ & 28 & 13 & 16 & 3 & 0 & \multirow[b]{2}{*}{4,10} & \multirow[b]{2}{*}{ Tinggi } \\
\hline & & $\%$ & 46,7 & 21,7 & 26,7 & 5,0 & 0,0 & & \\
\hline \multirow[t]{2}{*}{4} & \multirow{2}{*}{$\begin{array}{l}\text { Informasi produk selalu ada } \\
\text { dan selalu didapat melalui } \\
\text { media elektronik ( } \mathrm{Tl} / \mathrm{Wa} \text {, } \\
\text { email) }\end{array}$} & $\mathrm{F}$ & 23 & 16 & 17 & 4 & 0 & \multirow[b]{2}{*}{3,97} & \multirow[b]{2}{*}{ Tinggi } \\
\hline & & $\%$ & 38,3 & 26,7 & 28,3 & 6,7 & 0,0 & & \\
\hline \multirow{2}{*}{\multicolumn{2}{|c|}{ Akumulasi Jawaban Responden }} & $\mathrm{F}$ & 90 & 71 & 64 & 15 & 0 & \multirow[b]{2}{*}{3,98} & \multirow[b]{2}{*}{ Tinggi } \\
\hline & & $\%$ & 37,50 & 29,58 & 26,67 & 6,25 & 0,00 & & \\
\hline
\end{tabular}

Hasil Penelitian menunjukkan bahwa akumulasi rata-rata (Mean) semua jawaban per item dalam variabel Marketing Mix 4P (X1) sebesar 3,98 . Sehingga dapat disimpulkan bahwa secara umum variabel Marketing Mix 4P (X1) termasuk dalam kategori Tinggi.

Pada variabel Kualitas Pelayanan (X2) diukur menggunakan 15 indikator. Masing-masing jawaban memiliki nilai, kemudian skor jawaban diakumulasikan yang selanjutnya digunakan untuk mengkategorikan variabel berdasarkan rata-rata jawaban responden. Berikut disajikan distribusi frekuensi tanggapan responden terhadap variabel Kualitas Pelayanan .

Tabel 5.2

Distribusi Tanggapan Responden pada Variabel Kualitas Pelayanan

\begin{tabular}{|c|c|c|c|c|c|c|c|c|c|}
\hline \multirow{2}{*}{ No } & \multirow{2}{*}{ Item pada Kualitas Pelayanan (X2) } & & \multicolumn{5}{|c|}{ Alternatif Jawaban } & \multirow{2}{*}{ Mean } & \multirow{2}{*}{ Kategor } \\
\hline & & & ss & s & $\mathbf{N}$ & TS & STS & & \\
\hline \multirow[t]{2}{*}{1} & Pengiriman produk cepat & $\mathrm{F}$ & 13 & 29 & 13 & 5 & 0 & \multirow[b]{2}{*}{3,83} & \multirow[b]{2}{*}{ Tinggi } \\
\hline & & $\%$ & 21,7 & 48,3 & 21,7 & 8,3 & 0,0 & & \\
\hline \multirow[t]{2}{*}{2} & \multirow{2}{*}{$\begin{array}{l}\text { Waktu yang dibutuhkan untuk staffing dan } \\
\text { penataan produk baik dan tertata }\end{array}$} & $\mathrm{F}$ & 17 & 28 & 13 & 2 & 0 & \multirow{2}{*}{4,00} & \multirow[b]{2}{*}{ Tinggi } \\
\hline & & $\%$ & 28,3 & 46,7 & 21,7 & 3,3 & 0,0 & & \\
\hline \multirow[t]{2}{*}{3} & \multirow[t]{2}{*}{ kondisi produk sesuai dengan Physiknya } & $\mathrm{F}$ & 13 & 28 & 15 & 4 & 0 & \multirow[b]{2}{*}{3,83} & \multirow[b]{2}{*}{ Tinggi } \\
\hline & & $\%$ & 21,7 & 46,7 & 25,0 & 6,7 & 0,0 & & \\
\hline \multirow[t]{2}{*}{4} & \multirow{2}{*}{$\begin{array}{l}\text { lkan sesuai dengan spek dari permintaan } \\
\text { konsumen }\end{array}$} & $\mathrm{F}$ & 7 & 37 & 12 & 4 & 0 & \multirow{2}{*}{3,78} & \multirow[b]{2}{*}{ Tinggi } \\
\hline & & $\%$ & 11,7 & 61,7 & 20,0 & 6,7 & 0,0 & & \\
\hline \multirow[t]{2}{*}{5} & \multirow[t]{2}{*}{ Akurasi penataan ikan cukup baik } & $\mathrm{F}$ & 9 & 32 & 17 & 2 & 0 & \multirow{2}{*}{3,80} & \multirow[b]{2}{*}{ Tinggi } \\
\hline & & $\%$ & 15,0 & 53,3 & 28,3 & 3,3 & 0,0 & & \\
\hline \multirow[t]{2}{*}{6} & \multirow{2}{*}{$\begin{array}{l}\text { PO ( order pembelian ) sesuai dengan } \\
\text { permintaan konsumen. }\end{array}$} & $\mathrm{F}$ & 10 & 29 & 18 & 3 & 0 & \multirow{2}{*}{3,77} & \multirow{2}{*}{ Tinggi } \\
\hline & & $\%$ & 16,7 & 48,3 & 30,0 & 5,0 & 0,0 & & \\
\hline \multirow[t]{2}{*}{7} & \multirow{2}{*}{$\begin{array}{l}\text { PT. EPM memberikan jaminan kualitas produk } \\
\text { ikan }\end{array}$} & $\mathrm{F}$ & 8 & 31 & 19 & 2 & 0 & \multirow[b]{2}{*}{3,75} & \multirow[b]{2}{*}{ Tinggi } \\
\hline & & $\%$ & 13,3 & 51,7 & 31,7 & 3,3 & 0,0 & & \\
\hline 8 & PT. EPM bersedia memberikan fleksibilitas & $\mathrm{F}$ & 11 & 33 & 13 & 3 & 0 & & \\
\hline & & $\%$ & 18,3 & 55,0 & 21,7 & 5,0 & 0,0 & 3,87 & Tinggi \\
\hline 9 & PT. EPM memberikan jaminan produk ikan & $\mathrm{F}$ & 12 & 30 & 15 & 3 & 0 & & \\
\hline & & $\%$ & 20,0 & 50,0 & 25,0 & 5,0 & 0,0 & 3,85 & Tinggi \\
\hline 10 & PT.EPM member keyakinan produk yang bagus & $\mathrm{F}$ & 10 & 32 & 14 & 4 & 0 & & \\
\hline & kepada konsumen & $\%$ & 16,7 & 53,3 & 23,3 & 6,7 & 0,0 & 3,80 & Tinggi \\
\hline 11 & PT. EPM memperhatikan masukan - masukan & $\mathrm{F}$ & 8 & 32 & 16 & 4 & 0 & 272 & Tinari \\
\hline & & $\%$ & 13,3 & 53,3 & 26,7 & 6,7 & 0,0 & $3, / 3$ & linggI \\
\hline
\end{tabular}




\begin{tabular}{|c|c|c|c|c|c|c|c|c|c|}
\hline \multirow{2}{*}{ No } & \multirow{2}{*}{ Item pada Kualitas Pelayanan (X2) } & & \multicolumn{5}{|c|}{ Alternatif Jawaban } & \multirow{2}{*}{ Mean } & \multirow{2}{*}{ Kategori } \\
\hline & & & SS & $\mathbf{S}$ & $\mathbf{N}$ & TS & STS & & \\
\hline \multirow[t]{2}{*}{12} & \multirow{2}{*}{$\begin{array}{l}\text { PT. EPM bersedia menerima saran dan } \\
\text { masukan mengenai mutu produk dari } \\
\text { konsumen }\end{array}$} & $\mathrm{F}$ & 8 & 33 & 15 & 4 & 0 & \multirow[b]{2}{*}{3,75} & \multirow[b]{2}{*}{ Tinggi } \\
\hline & & $\%$ & 13,3 & 55,0 & 25,0 & 6,7 & 0,0 & & \\
\hline \multirow[t]{2}{*}{13} & \multirow{2}{*}{$\begin{array}{l}\text { PT. EPM menyediakan tempat penyimpana } \\
\text { ikan yang bersih }\end{array}$} & $\mathrm{F}$ & 20 & 22 & 15 & 3 & 0 & \multirow[b]{2}{*}{3,98} & \multirow[b]{2}{*}{ Tinggi } \\
\hline & & $\%$ & 33,3 & 36,7 & 25,0 & 5,0 & 0,0 & & \\
\hline \multirow[t]{2}{*}{14} & \multirow{2}{*}{$\begin{array}{l}\text { PT. EPM menyediakan deng sirkulasi yang baik } \\
\text { Cold storage sirkulasi baik }\end{array}$} & $\mathrm{F}$ & 27 & 16 & 14 & 3 & 0 & \multirow[b]{2}{*}{4,12} & \multirow[b]{2}{*}{ Tinggi } \\
\hline & & $\%$ & 45,0 & 26,7 & 23,3 & 5,0 & 0,0 & & \\
\hline \multirow[t]{2}{*}{15} & \multirow{2}{*}{$\begin{array}{l}\text { PT. EPM menyiapakn pembatas atas peta } \\
\text { produk }\end{array}$} & $\mathrm{F}$ & 25 & 18 & 15 & 2 & 0 & \multirow[b]{2}{*}{4,10} & \multirow[b]{2}{*}{ Tinggi } \\
\hline & & $\%$ & 41,7 & 30,0 & 25,0 & 3,3 & 0,0 & & \\
\hline & \multirow{2}{*}{ Akumulasi Jawaban Responden } & $\mathrm{F}$ & 198 & 430 & 224 & 48 & 0 & \multirow{2}{*}{3,86} & \multirow[b]{2}{*}{ Tinggi } \\
\hline & & $\%$ & 22,00 & 47,78 & 24,89 & 5,33 & 0,00 & & \\
\hline
\end{tabular}

Hasil Penelitian menunjukkan bahwa akumulasi rata-rata (Mean) semua jawaban per item dalam variabel Kualitas Pelayanan (X2) sebesar 3,86 . Sehingga dapat disimpulkan bahwa secara umum variabel Kualitas Pelayanan (X2) termasuk dalam kategori Tinggi.

Pada variabel Motivasi (X3) diukur menggunakan 3 indikator. Masing-masing jawaban memiliki nilai, kemudian skor jawaban diakumulasikan yang selanjutnya digunakan untuk mengkategorikan variabel berdasarkan rata-rata jawaban responden. Berikut disajikan distribusi frekuensi tanggapan responden terhadap variabel Motivasi (X3).

Tabel 5.3

Distribusi Tanggapan Responden pada Variabel Motivasi (X3)

\begin{tabular}{|c|c|c|c|c|c|c|c|c|c|}
\hline \multirow{2}{*}{ No } & \multirow{2}{*}{ Item pada Motivasi (X3) } & & \multicolumn{5}{|c|}{ Alternatif Jawaban } & \multirow{2}{*}{ Mean } & \multirow{2}{*}{ Kategori } \\
\hline & & & SS & $\mathbf{S}$ & $\mathbf{N}$ & TS & STS & & \\
\hline \multirow[t]{2}{*}{1} & \multirow{2}{*}{$\begin{array}{l}\text { Agen selalu membeli ikan di } \\
\text { PT. EPM karena margin lebih } \\
\text { besar }\end{array}$} & $\mathrm{F}$ & 6 & 39 & 10 & 5 & 0 & \multirow[b]{2}{*}{3,77} & \multirow[b]{2}{*}{ Tinggi } \\
\hline & & $\%$ & 10,0 & 65,0 & 16,7 & 8,3 & 0,0 & & \\
\hline \multirow[t]{2}{*}{2} & Agen mendapat harga lebih & $\mathrm{F}$ & 6 & 34 & 16 & 4 & 0 & \multirow[b]{2}{*}{3,70} & \multirow[b]{2}{*}{ Tinggi } \\
\hline & $\begin{array}{l}\text { murah dari pabrik Pesang } \\
\text { PT. EPM }\end{array}$ & $\%$ & 10,0 & 56,7 & 26,7 & 6,7 & 0,0 & & \\
\hline \multirow[t]{2}{*}{3} & Pelayanan lebih ramah dan & $\mathrm{F}$ & 13 & 33 & 9 & 5 & 0 & \multirow{2}{*}{3,90} & \multirow{2}{*}{ Tinggi } \\
\hline & menyenangkan & $\%$ & 21,7 & 55,0 & 15,0 & 8,3 & 0,0 & & \\
\hline \multirow{2}{*}{\multicolumn{2}{|c|}{ Akumulasi Jawaban Responden }} & $\mathrm{F}$ & 25 & 106 & 35 & 14 & 0 & \multirow{2}{*}{3,79} & \multirow{2}{*}{ Tinggi } \\
\hline & & $\%$ & 13,89 & 58,89 & 19,44 & 7,78 & 0,00 & & \\
\hline
\end{tabular}

Hasil Penelitian menunjukkan bahwa akumulasi rata-rata (Mean) semua jawaban per item dalam variabel Motivasi (X3) sebesar 3,79.

Sehingga dapat disimpulkan bahwa secara umum variabel Motivasi (X3) termasuk dalam kategori Tinggi.

Pada variabel Y Kinerja (Penjualan) diukur menggunakan 2 indikator. Masing-masing jawaban memiliki nilai, kemudian skor jawaban diakumulasikan yang selanjutnya digunakan untuk mengkategorikan variabel berdasarkan rata-rata jawaban responden.

Hasil Penelitian menunjukkan bahwa akumulasi rata-rata (Mean) semua jawaban per item dalam variabel Y Kinerja (Penjualan) sebesar 3,86 . Sehingga dapat disimpulkan bahwa secara umum variabel Y Kinerja (Penjualan) termasuk dalam kategori Tinggi. 
Tahap pertama dari uji kecocokan ini ditujukan untuk mengevaluasi secara umum derajat kecocokan atau Goodness of Fit (GOF) antara data dengan model. Tidak satupun dari ukuran-ukuran GOF atau GOFI secara eksklusif dapat digunakan sebagai dasar evaluasi kecocokan keseluruhan model. Petunjuk terbaik dalam menilai kecocokan model adalah teori substantive yang kuat.

Tabel 5.5

Hasil Goodness of fit Index (Inner Model)

\begin{tabular}{|c|c|c|c|}
\hline $\begin{array}{c}\text { Goodness of fit } \\
\text { Index }\end{array}$ & $\begin{array}{c}\text { Cut of } \\
\text { Value }\end{array}$ & Hasil & Keterangan \\
\hline FIT & $>0,500$ & 0,688 & Model good fit \\
\hline AFIT & $>0,500$ & 0,675 & Model good fit \\
\hline GFI & $>0,900$ & 0,959 & Model good fit \\
\hline SRMR & $<0,080$ & 0,343 & Model Poor fit \\
\hline
\end{tabular}

Model yang diajukan dalam penelitian ini memiliki nilai SRMR sebesar 0,343, dikarenakan nilai SRMR lebih besar dari 0,08, maka dapat disimpulkan bahwa model dinyatakan Poor fit.

Suatu variabel dikatakan mempunyai validitas yang baik terhadap konstruk atau variabel latennya jika nilai-t muatan faktornya lebih besar dari nilai kritis $(\geq 1,96)$ dan/atau muatan faktor standarnya $\geq 0,50$. Sedangkan evaluasi terhadap reliabilitas dari model pengukuran dalam GSCA dapat menggunakan Constuct Reliability ( $C R \geq 0,70)$ dan AverageVariance Extracted (AVE $\geq 0,50$ ). Rekapitulasi hasil evaluasi validitas dan reliabilitas dapat dilihat pada tabel berikut:

Tabel 5.6

Evaluasi Model Pengukuran (Outer Model)

\begin{tabular}{|c|c|c|c|c|c|c|c|c|}
\hline \multirow{3}{*}{ Variabel Laten } & \multirow{3}{*}{$\begin{array}{l}\text { Variabel } \\
\text { Teramati }\end{array}$} & \multirow{2}{*}{\multicolumn{2}{|c|}{$\begin{array}{c}\begin{array}{c}\text { Validitas } \\
\text { Konvergen }\end{array} \\
(\mathrm{LF}>0,5=\text { Valid })\end{array}$}} & \multirow{3}{*}{ 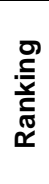 } & \multirow{2}{*}{\multicolumn{2}{|c|}{$\begin{array}{c}\text { Validitas Diskriminan } \\
\text { (AVE }>0,5=\text { Valid })\end{array}$}} & \multirow{2}{*}{\multicolumn{2}{|c|}{$\begin{array}{c}\text { Cronbach Reliability (CR } \\
>0,7)\end{array}$}} \\
\hline & & & & & & & & \\
\hline & & $\begin{array}{c}\text { Outer } \\
\text { Loading }\end{array}$ & Ket & & AVE & Kesimpulan & CR & Keterangan \\
\hline \multirow{4}{*}{$\begin{array}{l}\text { Marketing Mix 4P } \\
\text { (X1) }\end{array}$} & $\mathrm{X} 1.1$ & 0,887 & Valid & 4 & \multirow{4}{*}{0,821} & \multirow{4}{*}{ Valid } & \multirow{4}{*}{0,926} & \multirow{4}{*}{ Reliabel } \\
\hline & $\mathrm{X} 1.2$ & 0,915 & Valid & 2 & & & & \\
\hline & $\mathrm{X} 1.3$ & 0,903 & Valid & 3 & & & & \\
\hline & $\mathrm{X} 1.4$ & 0,918 & Valid & 1 & & & & \\
\hline \multirow{5}{*}{$\begin{array}{l}\text { Service Quality } \\
\text { (X2) }\end{array}$} & $\mathrm{X} 2.1$ & 0,790 & Valid & 5 & \multirow{5}{*}{0,696} & \multirow{5}{*}{ Valid } & \multirow{5}{*}{0,889} & \multirow{5}{*}{ Reliabel } \\
\hline & $\mathrm{X} 2.2$ & 0,826 & Valid & 3 & & & & \\
\hline & $\mathrm{X} 2.3$ & 0,816 & Valid & 4 & & & & \\
\hline & $X 2.4$ & 0,842 & Valid & 2 & & & & \\
\hline & $\mathrm{X} 2.5$ & 0,893 & Valid & 1 & & & & \\
\hline \multirow{3}{*}{ Motivation (X3) } & X3.1 & 0,847 & Valid & 3 & \multirow{3}{*}{0,769} & \multirow{3}{*}{ Valid } & \multirow{3}{*}{0,849} & \multirow{3}{*}{ Reliabel } \\
\hline & X3.2 & 0,889 & Valid & 2 & & & & \\
\hline & X3.3 & 0,894 & Valid & 1 & & & & \\
\hline \multirow{2}{*}{ Kinerja (Y) } & Y.1 & 0,956 & Valid & 1 & \multirow{2}{*}{0,902} & \multirow{2}{*}{ Valid } & \multirow{2}{*}{0,888} & \multirow{2}{*}{ Reliabel } \\
\hline & Y.2 & 0,943 & Valid & 2 & & & & \\
\hline
\end{tabular}


Berdasarkan tabel 5.6 diatas dapat diketahui bahwa seluruh nilai Loading factor $\geq 0,50$ (Valid), dan nilai AVE $\geq 0,50$ (Valid), Sedangkan dari hasil perhitungan reliabilitas menunjukkan bahwa semua nilai Cronbach Reliability $(C R) \geq 0,70$ (Reliabel). Dengan demikian dapat disimpulkan bahwa semua variabel-variabel laten tersebut memiliki indikator yang baik dan layak.

Bagian ini berhubungan dengan evaluasi terhadap koefisien-kofisien atau parameter-parameter yang menunjukkan hubungan kausal atau pengaruh satu variabel laten terhadap variabel laten lainnya. Sebuah hubungan kausal dinyatakan tidak signifikan jika nilai critical ratio (C.R) berada diantara rentang -1.96 dan 1.96 dengan tingkat signifikansi 0,05. Dengan bantuan aplikasi program GSCA diperoleh hasil estimasi nilai critical ratio model struktural. Secara ringkas hasil perhitungan koefisienkoefisien tersebut disajikan dalam tabel berikut

\section{Tabel 5.7}

Hasil Estimasi dan pengujian Pengaruh Langsung

\begin{tabular}{|c|c|c|c|c|c|}
\hline \multicolumn{3}{|c|}{ Pengaruh antar variabel Latent } & \multirow{2}{*}{$\begin{array}{l}\text { Koefisien } \\
\text { Jalur }\end{array}$} & \multirow{2}{*}{ CR } & \multirow{2}{*}{ Kesimpulan } \\
\hline Var. Penyebab & $-->$ & Var. Akibat & & & \\
\hline $\begin{array}{c}\text { Marketing Mix 4P } \\
\text { (X1) }\end{array}$ & $-->$ & Motivation (X3) & 0,381 & 1,97 & Signifikan \\
\hline $\begin{array}{l}\text { Marketing Mix 4P } \\
(\mathrm{X} 1)\end{array}$ & $-->$ & Kinerja $(Y)$ & 0,332 & 1,93 & $\begin{array}{c}\text { Tidak } \\
\text { Signifikan }\end{array}$ \\
\hline Service Quality (X2) & $->$ & Motivation (X3) & 0,509 & 2,78 & Signifikan \\
\hline Service Quality (X2) & $-->$ & $\mathrm{K}$ & 2 & 0,12 & $\begin{array}{c}\text { Tidak } \\
\text { Signifikan }\end{array}$ \\
\hline Motivation (X3) & $-->$ & Kinerja (Y) & 0,587 & 4,85 & Signifikan \\
\hline
\end{tabular}

Berdasarkan tabel 5.7 diatas dapat diketahui hasil estimasi dan pengujian hipotesis.

Dari hasil analisis yang telah dibahas pada hasil penelitian secara empiris maka kami jelaskan hasilnya sebagai berikut:

1. Diketahui Variabel Marketing Mix 4P memiliki pengaruh positif terhadap Motivation, artinya semakin tinggi Marketing Mix 4P maka akibatnya akan meningkatkan variabel Motivation membeli - agen Perusahaan, dimana koefisien Jalur yang diperoleh adalah 0,381 dengan nilai CR sebesar 1,97 maka hipotesis pertama diterima . Karena nilai CR lebih besar dari critical value $(1,97>1,96)$, maka hipotesis statistik menyatakan $\mathrm{HO}$ ditolak, artinya variabel Marketing Mix 4P memiliki pengaruh yang Signifikan, terhadap variabel Motivation). Hasil penelitian tersebut dibandingkan penelitian terdahulu mendukung pada Penelitian Hidyati 2006 bahwa Motivasi membeli memiliki pengaruh positifdan signifikan terhadap kinerja Koperasi.

2. Diketahui variabel Service Quality memiliki pengaruh positif terhadap Motivation artinya semakin tinggi Service Quality (X2) maka akibatnya akan meningkatkan variabel Motivation (X3), dimana koefisien Jalur yang diperoleh adalah 0,509 dengan nilai CR sebesar 2,78 dan diterima . Karena nilai CR lebih besar dari critical value $(2,78>1,96)$, maka hipotesis statistik menyatakan $\mathrm{HO}$ ditolak, artinya variabel Service Quality memiliki pengaruh yang Signifikan, terhadap variabel Motivation. Hasil penelitian tersebut dibandingkan penelitian terdahulu 
mendukung pada Penelitian Depary 2010 , hasil analisisnya menyatakan bahwa faktor - faktor yang mempengaruhi kinerja pemasaran adalah kualitas pelayanan secara signifikan.

3. Diketahui Variabel Marketing Mix 4P tidak signifikan terhadap Kinerja, artinya semakin tinggi Marketing Mix 4P maka akibatnya akan meningkatkan variabel Kinerja, hal ini dibuktikan dari hasil yang diperoleh dari 0,332 dengan nilai CR sebesar 1,93 diterima. Karena nilai CR lebih kecil dari critical value $(1,93<1,96)$, maka hipotesis statistik menyatakan $\mathrm{HO}$ diterima, artinya variabel Marketing Mix 4P memiliki pengaruh yang Tidak Signifikan, terhadap variabel Kinerja . Hasil penelitian tersebut dibandingkan penelitian terdahulu mendukung pada Penelitian Astuti, 2015 hasil analisisnya Pengaruh Kualitas layanan dan Bauran Pemasaran terhadap loyalitas Nasabah berpengaruh positif secara signifikan.

4. Diketahui variabel Service Quality tidak signifikan terhadap Kinerja (Y), hal ini dibuktikan dengan koefisien Jalur yang diperoleh adalah $-0,022$ dengan nilai CR sebesar 0,12 hasil analisis diterima . Karena nilai CR lebih kecil dari critical value $(0,12<1,96)$, maka hipotesis statistik menyatakan HO diterima, artinya variabel Service Quality memiliki pengaruh yang Tidak Signifikan, terhadap variabel Kinerja . Hasil penelitian tersebut dibandingkan penelitian terdahulu Yuliari dan Riyadi, 2015 mendukung pada Penelitian Hasil Penelitannya menyatakan bahwa Bauran Pemasaran berpengaruh dan Kualitas Pelayanan terhadap keputusan membeli secara signifikan.

5. Diketahui variabel Motivation memiliki pengaruh positif terhadap Kinerja ( $Y$ ), artinya semakin tinggi Motivation maka akibatnya akan meningkatkan variabel Kinerja, dimana koefisien Jalur yang diperoleh adalah 0,587 dengan nilai CR sebesar 4,85. Karena nilai CR lebih besar dari critical value $(4,85>1,96)$, maka hipotesis statistik menyatakan $\mathrm{H} 0$ ditolak, artinya variabel Motivation memiliki pengaruh yang Signifikan, terhadap variabel Kinerja. Hasil penelitian tersebut dibandingkan penelitian terdahulu mendukung pada Penelitian Hidayati,2006 bahwa Motivasi membeli berpengaruh positif dan signifikan terhadap pertisipasi.

\section{SIMPULAN DAN SARAN}

Maketing Mix dan Kualitas layanan perlu dikembangkan sehingga target kinerja Pemasaran bisa lebih maksimal.

1. Hasil analisis menunjukkan bahwa terdapat pengaruh positif dan signifikan dari variabel Marketing Mix 4P (X1) terhadap Motivasi Membeli (X3) pada konsumen (sebagai agen) PT. Eratma Putra Mandiri Banyuwangi, yaitu dengan pengaruh sebesar 0,381 dengan CR 1,97 > 1,96 (signifikan).

2. Hasil analisis menunjukkan bahwa terdapat pengaruh positif dan signifikan dari variabel Kualitas Layanan (X2) terhadap Motivasi Membeli (X3) pada konsumen (sebagai agen) PT. Eratma Putra Mandiri Banyuwangi, yaitu dengan pengaruh sebesar 0,509 dengan CR 2,78 > 1,96 (signifikan). 
3. Hasil analisis menunjukkan bahwa terdapat pengaruh positif dan tidak signifikan dari variabel Marketing Mix 4P (X1) terhadap Kinerja Pemasaran ( $\mathrm{Y}$ ) pada konsumen (sebagai agen) PT. Eratma Putra Mandiri Banyuwangi, yaitu dengan pengaruh sebesar 0,332 dengan CR 1,93 < 1,96 (tidak signifikan).

4. Hasil analisis menunjukkan bahwa terdapat pengaruh negatif dan tidak variabel Kualitas Layanan (X2) terhadap Kinerja Pemasaran (Y) pada konsumen (sebagai agen) PT. Eratma Putra Mandiri Banyuwangi, yaitu dengan pengaruh sebesar $-0,022$ dengan $C R$ $0,12<1,96$ (tidak signifikan).

5. Hasil analisis menunjukkan bahwa terdapat pengaruh positif dan signifikan dari variabel Motivasi Membeli (X3) terhadap Kinerja Pemasaran (Y) pada konsumen (sebagai agen) PT. Eratma Putra Mandiri Banyuwangi, yaitu dengan pengaruh sebesar 0,587 dengan CR 4,85> 1,96 (signifikan).

\section{DAFTAR PUSTAKA}

Booms, B. H. and Mary-Joe Bitner, 1981, Marketing Strategis and Organisation.

Bollen, Kenneth A, 1989, Struktural Equation with Latent Variables, John Wiley \& Sons.

Bollen, Kenneth A., dan J. Scot Long (editors), 1993, Testing Struktural Equation Model, Sage Publication.

Campbell, D.T., and Fiske, D.A. 1959. "Convergent and Discriminant Validation by the multitrait-multimethod matrix,"Psychological Bulletin (56:1), pp. 81-105.

Fornel, C. dan D.F. Larcker. (1981). Evaluating Struktural Equation Models with Ubobserved Variable and Measurement Error, Journal of Marketing.

Fandy Tjiptono,PHD Gregorius Chandra, 2016 Service Quality fan Satisfaction.

Ghozali, Imam. (2005). Struktural Equation Modeling Dengan Program LISREL 8.54, Badan Penerbit Universitas Diponegoro, Persamaan Struktural

Hidayati,2006, Pengaruh Rasa memiliki dan Kualitas Layanana sertaMotivasi membeli dan Partispasi Anggota terhadap Kinerja Koperasi Pegawai esia di Kota Malang.

Hwang, H., H. Montreal, and Y. Takane. 2004. Generalized Structured Component Analysis. Psychometrika. Vol 69. No 1. p 81-99.

Hwang, H. 2009. Regularized Generalized Structured Component Analysis. Psychometrika. Vol 70. No 3. p 517-530

Hwang, H., M. R. Ho, and J. Lee. 2010. Generalized Structured Component Analysis with Latent Interactions. Psychometrika. Vol 75. No 2. p 228-242.

Hwang H. (tanpa tahun). VisualGSCA 1.0-A Graphical User Interface Software Program for Generalized Structured Component Analysis. Canada: Departement of Psychology, McGill University 
Jöreskog, Karl. (1999). Interpretation of $R^{2}$ revisited, tersedia di http://www.ssicentral.com/lisrel/advancedtopics.html.

J.H. Donnelly and W.R. George, Eds. Chicago, Structures for Service Firm, in Marketing of Services.

Kotler, Philip dan Kevin Lane Keller. 2016. Alih Bahasa : Benyamin Molan.Manajemen Pemasaran. Edisi Ketiga belas. Jilid 1 dan 2. Cetakan Keempat. PT. Indeks.Jakarta.

Kotler, Philip dan Gary Amstrong. 2008. Prinsip-Prinsip Pemasaran. Jilid 1 dan 2 edisi Keduabelas. Erlangga. Jakarta.

Petri, Hebert L. (1981). Motivation: Theory and Research. Belmont. California: Wadsworth Publishing Company.

Sugiyono. (2009). Statistika untuk Penelitian, Bandung: Alfabet.

Sudjana. 2005. Metoda Statistika, Edisi 6, Bandung : Tarsito

Zeithaml, Valeri A.Jo Merry jo Bitner (1988). "Services Marekting Integratred Customer Focus across the firm".chapter 1 page 2.

http://www.pustaka-deptan.go.id), diakses tanggal 14 Oktober 2015 Sunyoto 2012,KonsepRiset Pamsaran dan Perilaku Konsumen.

http://www.google.co.idgws_rd=cr,ssl\&ei=leckVtvwH8SluAStjaLAB $Q \# q=K A J I A N M A N A J E M E N+P E M A S A R A N+I K A N+P I N D A N G+L A Y A N G+$ DI+KOTA+TEGAL.

https://almanhaj.or.id/3654-curang-dalam-timbangan-dan-takaranmengundang-kerusakan-di-dunia-dan-celaka-di-akherat.html https://www.simplypsychology.org/maslow-hierachy-of-needs(1).gif 